\title{
Maghrebian toponym variants in Hungarian school atlases
}

Absztrakt: A földrajzinév-változatok rendezett táblázata által a konkordancia-vizsgálat mélyebb összehasonlításokat tesz lehetôvé. A Maghreb-országok (Marokkó, Algéria, Tunézia) esetében a gyarmati idôk utáni ún. arabositási folyamat, illetve a politikai fordulatok révén számos helynév megváltozott, leginkább a városnevek.

Az atlaszok általában az elözö kiadványok gyakorlatát követik, de mégis vannak névváltozatok. E cikk a Maghreb-országok helyneveinek változatait állítja össze néhány 20. és 21. századi magyar iskolai atlasz névanyaga alapján. Továbbá megvizsgálja, hogy a magyar térképész egyetemi hallgatók hogyan ejtik az atlaszokból gyüjtött neveket, illetve azt, hogy kiejtésüket az arabok mennyire értenék meg.

Az eredmények azt mutatják, hogy a francia átírás szerint leírt arab nevek olvasása a magyar hallgatóknak gondot okozott. Két fö következtést lehetett ebböl levonni: a magyar fiataloknak nehézséget jelentett a helynevek kiejtése, az arabok pedig nem értették volna meg óket, azaz a kommunikáció megakadna. Bár a Maghreb-régióban a helyneveket arabul és franciául írják, a magyar olvasók a helyi környezettôl eltérố módon használják a földrajzi neveket, igyekezvén azokat a nyelvükhöz igazitani (magyaros átírás). Ezért a helynevek szótártani feldolgozása magába foglalja a helynevek irását és kiejtését is.

Abstract: Concordance provides variants of a name and thus inaugurates a more in-depth representative reference. Besides, city names shift more frequently than other geographical names, which can be explained by the end of colonialism, various political upheavals, or other reasons. In the particular case of the Maghreb, Arabization has led to a noticeable transformation of many toponyms.

Atlases usually imitate the former ones; yet, variations occur. This study aims to collect the toponym variants of the Maghreb region (Morocco, Algeria, Tunisia) from several Hungarian $20^{\text {th }}$ and $21^{\text {st }}$ school atlases and address the entries' pronunciation by the Hungarian students. Thus, students were asked to pronounce the various place names collected from the atlases, which enabled an interpretation of how understandable they are to Arabs.

Results unveiled the intricacy behind the pronunciation. Two main conclusions emerged; Hungarian students encountered challenges reading the toponyms, and Arabic speakers could not identify the names either, which causes a cut in communication. Hungarians use geographic names that are foreign to their environment and language in diverse settings, hence trying to adapt them to their linguistic context. The Maghreb region uses Arabic and French to present the place names. Consequently, the toponym's lexicographical treatment will, therefore, consist of both the presentation of the toponymic term and the pronunciation of the entries.

Kulcsszavak: konkordancia, iskolai atlaszok, helynevek Keywords: concordance, school atlases, toponymy

\section{Introduction}

Geographic names are proper names of geographical features. They are characterized by different meanings, contexts, and histories, thus being an essential geographical space feature. Through them, the land is charged with meanings.

The nature of the people inhabiting the land manifests itself in the giving, maintaining, or shifting of the place names. Place names possess a humanlike character in the sense that they evolve and change. Moreover, because human beings need to give name references to the land to distinguish a particular area from another, place names migrate, expand, disappear, and rejuvenate with the people's needs.
Names yield a linguistic frame of reference where the toponym should preserve the place name's identification both in writing and oral form. Furthermore, the establishment of links between the entries and the names of a large body of reference would make it possible to show to the user, in the form of a concordance, a representation of the actual use of the toponym. Identifying, processing, and normalizing place names and their numerous variants is valuable in various applications, such as: advancing the efficiency of machine translation, place name dictionaries for human translators, segmentation and morphological analysis of Arabic/ French-Hungarian texts, and as a database for gazetteers.

\section{Place names}

Place name holds diverse meanings in different places. A geographical place name is viewed as a designation given to either natural or artificial landscape features, which constitutes a geographical reference. According to the Economic and Social Council of the United Nations, the "geographical names can be classified into two groups: one group is called 'toponym', or feature names, which refer to physical entities and/or geographical configurations; the other group is simply called a place name, referring to names of the place where people inhabit or recognize" (Yamaguchi 1974). In this present paper, both terms will be used interchangeably. 
Place names carry some linguistic and pragmatic properties that distinguish them from the standard vocabulary. They may be employed by speakers with no knowledge of the target language, for instance, in travel information, route description, or navigation query context, where critical divergences from the official pronunciations are likely to occur. Whereas in standard vocabulary, the deviations will be less striking as speakers usually have at least some basic knowledge of the Target Language (TL). Besides, place names usually conserve orthographic features of some earlier historical stage of a language or bear trails of other languages that the TL has come into contact with through its historical expansion. Consequently, there is a probable existence of irregular grapheme-phoneme conformities that diverge from the present-day pronunciation rules.

A single place can have multiple names over time and place, and for various reasons. According to Orth and Payne (2003), "Confusion, uncertainty, and misunderstanding may occur when the name for an entity is spelled in different ways, when different names are used for the same place, when the same name is used for different places, or when a name is applied to a feature in an unexpected or different way from the general understanding of how it should apply."

The most straightforward source of variation in place names is their ability to change over time. Place names can also vary by language; a place name can be spelled differently in different languages. Most language-related placename variants are exonyms, which are commonly not used by the inhabitants of the place in question but are used by "an external community" (Jordan 2016) of people from different countries or with different languages. According to Zagórski, an exonym is "any relevant name which is not in MSA" (Modern standard Arabic), and it also applies to names in "other locally wellestablished languages and dialects" (Zagórski, 2010). Additionally, because different languages often use different scripts, there will be variations among different scripts.
Another source of name variant is transliteration and romanization. Transliteration is converting a text from one language to another, where each uses different characters. There are different transliteration schemes in use, and thus often transcribe the same word or place differently. Romanization, a type of transliteration, is converting a text in a language that uses a non-Roman script to a Roman script. Language variation is a source of variant names, especially names recorded in different scripts, such as Roman and Cyrillic scripts and Chinese characters. This is a typical problem for place names romanized in Hungarian. In other words, the romanization in Hungarian causes the name variants of Maghrebian names.

\section{The Maghreb situation}

Countries of the Maghreb present a rich toponymic patrimony because of the diversity of referents and references used in the nomination of its places and territories. They are countries of ancient civilizations that have experienced the passage of several people of different origins, languages, and traditions. They are situated on the road of invasions and human migrations and have undergone successive occupations of long duration, which marked the geographical landscape's denomination. This denomination is the consequence of multiple factors, old or recent, since it is the living reflection of a geographical, historical, linguistic, or ethnographic structure.

The possible variations of a Maghrebian toponym are summed up with examples set in bold below, where UN refers to the romanization system of Arabic names according to the United Nations Group of Experts on Geographical Names (https:// unstats.un.org/unsd/ungegn/).

1. Arabic or Berber endonyms with Arabic script:

a) Arabic الجديدة (French: El Jadida; UN: Al-Jadidah) is an Arabic word that means 'new'. It is the name of the Moroccan city known as Mazagan by Europeans, named after the Berber Banu Mazg'anna tribe. b) Arabic أكُادير (French: Agadir; UN: Agādīr) contains a Berber term that is widely used in the Maghreb. It is pronounced Ajdir in Tamazight (one of the Berber languages); it is the same word as the Arabic Jidar, which means 'wall'. It is known in the Eastern part of the Arab World as Aghādīr اجسادير or Ajādīr أغـادير or Ajadīr اجدير (Zagórski, 2018). Aghādīr is an artificially coined Arabic exonym resulting from the retranslation of the word Agadir from French using the usual pattern of Arabicizing European $\mathrm{g}$ with the letter ghayn.

c) Arabic أزمور (French: Azemmour; UN: Azammūr) derived from the Berber word Azemmur ('wild olive tree').

2. Endonyms with romanized script according to UNGEGN:

a) Ar-Ribāț (Arabic: الرباط; French: Rabat), where the 1 is assimilated with the first consonant of the word because the al precedes a word that starts with an $\mathrm{r}$.

b) Al-Qunayțirah (Arabic: القنيطرة; French: Kénitra) meaning the 'little bridge' in Arabic. It was known as Port-Lyautey during the protectorate era.

3. Exonyms by transliteration:

a) The locally used French versions (see examples above).

b) Esz-Szavíra, the Hungarian version for the UN-romanized Aṣ-Șawīra, French Essaouira, Arabic الصدويرة, or the Hungarian Tandzsa for the UN-romanized Țanjah, French Tanger, Arabic طنجة.

4. Real exonyms:

a) Essaouira, the town mentioned above, has been known by a variety of names throughout history. The current Arabic name means 'small wall'. Sidi Mgdul, the name of a saint buried in this city, is the original Berber toponym of this city. The location is later known as Amgdul, which the Europeans later changed to Mogador (Portuguese).

b) Mdiq commonly known Rincón (Spanish meaning 'corner'). 
c) Fnideq still known under the Spanish name Castillejos.

Casablanca, Ad-Dār al-Bayḍā

is the only Moroccan city to hold dual naming. It was previously denominated Anfa (meaning hill in Amazigh). Later, 'Casa Branca' by the Portuguese, and to 'Casa Blanca' during the Spanish protectorate. In 1755, it was renamed Ad-Dār al-Bayḍā by sultan Mohammed ben Abdellah.

\section{Historic, linguistic situation}

The Maghreb's linguistic situation is characterized by multilingualism. In Morocco, the coexisting of Berber, Moroccan Arabic or Darija, Standard Arabic, and French in the same territory are distinguished by their status and their areas of use. Berber and Moroccan Arabic are the languages of the immediate environment and everyday encounters, while standard Arabic and French are the languages of writing and the elite. The Arabic dialects are not traditional products of standard or classical Arabic distortion; rather, they are distinct, independent entities with roots in earlier spoken Arabic and have existed in the Arab world since ancient times, evolving over time and space. They are the real mother tongues and are vastly different phonetically, lexically, and grammatically. The French language entered the linguistic landscape at the same time as the Maghreb invasion (Algeria, 1830-1962; Tunisia, 1881-1956; Morocco, 19121956). Morocco's official languages are Standard Arabic and Amazigh (since 2011), also known as Berber; It is one of the western Mediterranean's oldest languages. The number of Berber speakers „may reflect between 35 and 40 percent of the total population" of Morocco (Caubet, 2008).

\section{The Maghrebian toponyms}

Toponyms from the Maghreb provide "information about their layers of formation through Antiquity, Middle Ages, and contemporary times" (Nissabouri, 2006).

The French, in their quest for dominance and space restructuring, altered the Moroccan toponymy, relocated several weekly markets or shifted the days of their development.
El Fasi (2005) provides some examples of toponyms that have been altered by the protectorate powers: Al-Aràis, was deformed by the Spanish to Larache; Ar-Rommàni, the word means pomegranate and the French named it Camp-Marchand; Asafi, the indigenous term is asif, which in most Berber dialects means river, deformed by the French as Safi; and Tittawin, sources in Berber, plural of tit, deformed into Tetuán by the Spanish.

The first Arabization was mainly an urban phenomenon. It first appears as a combination of terms: the traditional name is combined with an Arabic term describing the feature, Al-qasr Al-kabīr. The toponymy that was influenced by it always designates a „saint” either living or dead; Sidi Bel-Abbès (Algeria), Sidi Kacem (ex. Petitjean, Morocco), Sidi Bou-Saïd (Tunisia).

Following independence in 1956 , Morocco became actively involved in the reconstruction process and the claim of a „national cultural and linguistic identity based on two components: Arabity and Islam" (Akioud, 2018). Morocco sought to gradually exclude colonial languages (French and Spanish) from Moroccan public life. The Spanish names Villa Sanjurjo and Rincón have been replaced by Al-Husayma (Al Hoceima) and Mḍiq (M'diq), thus deprived of their original Amazigh names Tayzut and Taymart respectively.

The Moroccan territory has since known several recompositions. The different municipal (1959, 1992) and regional (1971, 1997) divisions that occurred reconstructed the toponymy of the country. Although the 1971 regional division was based on geographic landmarks, it was unable to anchor this cardinal toponymy in the collective perception of Moroccans. The toponymic rules of the 1992 division emphasized the promotion and recognition of the local territories. However, The "tribal system has been emptied of its mostly political content" (Boujrouf \& Hassani, 2008). As a result, several Berber communities have been forced to abandon their conventional territory management system in favour of one enforced by the central administration.
Another point worth mentioning is the nominations of territories used to be spontaneous, following the natural conditions of the environment, the tribal genealogy, and the everyday experience. In the $19^{\text {th }}$ century and at the beginning of the $20^{\text {th }}$ century, French administrators created maps of Morocco, Algeria, and Tunisia. The maps comprised toponymic data obtained inconsistently. Rules were published, and regulations intended to make an order in the procedures, but the rules themselves created confusion as they were internally inconsistent. For instance, 'el' and 'al' (El Jadida vs. Al-Jadida), 'in' and 'ain' (In Salah vs. Aï Salah), /s/ in 's' and 'ss' (Asilah vs. Assilah), /w/ sound as 'oua' or 'w' (Ouazzane vs. Wazane). Moreover, collecting names would demand a high level of linguistic proficiency. However, cartographers did not know the Arabic language sufficiently, not even to differentiate between the standard language and dialects or among various dialects themselves, neither Berber languages.

Individual judgment, biased imagination, and personal inclinations of the cartographers who were foreign to the country resulted in voluntaristic transcription of Maghrebian geographical names in French and introducing them into maps, which will manifest in a bilingual transcription of the place names.

\section{Methodology}

\section{Data collection}

The methodology used is descriptive theoretical literary analysis that consists of gathering relevant data from various source, in this case, the $20^{\text {th }}$ and $21^{\text {st }}$ century Hungarian school atlases. The choice of school atlases was because most people meet, for the first time, foreign place names in school. Moreover, the atlas is not the only influencing factor on how people memorize the name and spelling; the teacher's pronunciation also plays a crucial role in the foreign name adaptation. It provides a more profound impression on the young people. Moreover, only the geographical atlases of Hungarian 
schools are used, since the historical ones, in principle, should show the name as it was used in the time.

Moreover, the document analysis methodology requires that data be examined and interpreted in order to elicit meaning, gain understanding, and develop empirical knowledge.

- Conventionally, there are two methods of differentiating between Arabic and French in printed transcriptions. French is printed in roman fonts, while Arabic uses Arabic lettering. It is also important to note that these indications pose a phonetic significance, with one unique case of Casablanca, Ad-Dār al-Bay ḍ़.

- When significant variants of the same toponym occur in the same atlas, the variants are mentioned in the same line, enclosed in parentheses.

- Entries are mentioned in essentially standard dictionary order, using alphabetical order of the French language. They are sorted alphabetically.

- Each atlas is identified by its title and publication year.

\section{Interviews}

Semi-structured interviews were also used as a research method in this study. Several people of any age, who are below the educational standard, may not know what The Maghreb is, or what language its population uses. Hence, to avoid any deficiency of valuable results, Hungarian students have been used as target participants. Moreover, the interviews were conducted in English, where most Hungarian students were able to understand and follow the instructions.

Students of language majors were strictly avoided as they are likely to have increased linguistic awareness, independently of the languages involved. All participants are Hungarian students at the Institute of Cartography and Geoinformatics at Eötvös Loránd University. The choice of cartography students was driven by the fact that they are most predisposed to toponyms and specifically foreign place names.

Subject instruction is a vital concern in a non-native speech study; they may feel disquieted about being tested on their foreign language proficiency (in this case, French-Arabized variants of toponyms). French is far from being a popular foreign language in Hungary, which can be heeded in the statistics of how many people tried to take language exams at any level in Hungary between 2011 and 2020. According to NYAK, the popularity of languages among them was as follows: English $71 \%$, German 21\%, Esperanto 2.3\%, French 1.6\%, Lovari (the language of the Gypsy) $1.0 \%$, Spanish $1.0 \%$, Italian $1.0 \%$, and Russian $0.4 \%$ (https://nyak.oh.gov. $\mathrm{hu} / \mathrm{doc} / \mathrm{stat} / \mathrm{stat}$ disp.asp?strID=A0). Consequently, the recordings were introduced by a clear explanation of the study's goals. The participants were encouraged to employ any foreign language knowledge, regardless of potential mistakes. It was reiterated that the inquiry is not intended as proficiency on the phonetic performance and that correct pronunciation is neither expected nor desired. Although these oral instructions cannot wholly compensate for the somewhat contrived experimental situation, it may help to lessen the subjects' feelings of anxiety. The respondents were approached in a more friendly environment to avoid the setting-pressure that may arise.

The subjects were first presented with a map that shows the Maghreb region (Morocco, Algeria, and Tunisia). They then proceeded to read the lists of place names as isolated words. They were encouraged to read silently before pronouncing the name's pronunciation. Moreover, the toponym's repetition was inquired to apprehend some potential intra-speaker variation; they repeated individual names until they eventually arrived at their intended pronunciation. Since any delays and hesitations in the respondent's responses are recorded, this information can be used to estimate the degree of difficulty of some words. The detection of linguistic regularities that govern foreign place-names' pronunciation by non-native speakers will shed light on its effect on the smooth transmission of information.

Afterward, they listen to the correct pronunciation of the names read by me, a native speaker, and are encouraged to repeat the pronunciation. The aim was to compare the pronunciation produced in reading and repeating, which will allow us to yield conclusions about the particular influence of spelling pronunciation.

\section{Discussion}

The data record contains information on the following items.

- Official name form: the linguistically verified official name both in the French and Arabic variations.

- Phonetic transcription: of the Arabic official toponym, following the IPA chart.

- Geographical coordinates of the feature: latitude and longitude.

- Collected name variants: from the Hungarian $20^{\text {th }}$ and $21^{\text {st }}$ century school atlases, starting from the oldest.

- Etymology: the origin of the name.

- Standard Hungarian pronunciation: of the French variant of the place name.

- Transliteration: the attempted transliteration to ease the pronunciation.

- A case for comments and observations.

It is important to note that the place names data is being expanded and continuously updated and is still in a manuscript format. It is assumed that even with its present content, critical users may use the database to get at least preliminary information on different place names. The database presents name spellings (both in French and Arabic), and other information for practical purposes only, reflecting mostly the actual situation. It does not refer to certain political entities as independent states if they are not internationally recognized.

Atlases quietly imitate the former atlases with occurring changes. When having name concordance, we can quickly get to the name variants and easily understand the presently accepted name. Thus, the database will enable a close investigation of the place names change, and whether the Hungarian atlases follow the name changes in time or are delayed. The collected variants also display whether the written form in the school atlases follows the Hungarian pronunciation, 


\begin{tabular}{|l|rl|}
\hline Orthographical differences & \multicolumn{1}{|c|}{$\begin{array}{l}\text { Le Kef / El-Kef } \\
\text { Ain Salah / In Sallah }\end{array}$} \\
\hline $\begin{array}{l}\text { The language of the original name } \\
\text { has changed }\end{array}$ & $\begin{array}{l}\text { The change in usage in 'Tetuán' (1962) and 'Tétouan' (1973) is } \\
\text { the result of the change of the toponym in 1956, from Spanish } \\
\text { to French version. }\end{array}$ \\
\hline $\begin{array}{l}\text { The form of the original name has } \\
\text { changed due to decolonization }\end{array}$ & $\begin{array}{l}\text { Philippeville vs Skikda } \\
\text { Bône vs Annaba }\end{array}$ \\
\hline $\begin{array}{l}\text { The form of the original name has } \\
\text { changed after decolonization }\end{array}$ & $\begin{array}{l}\text { Ksar Es-Souk / Errachidia } \\
\text { Louis Gentil / Youssoufia } \\
\text { Fedala / Mohammedia }\end{array}$ \\
\hline $\begin{array}{l}\text { Unchanged French/Spanish } \\
\text { toponym }\end{array}$ & $\begin{array}{l}\text { Ifni (Sidi Ifni is the Arabized form) } \\
\text { The Spanish toponym 'El Aaiún' is a transliteration } \\
\text { of the Maghrebi Arabic name Layoun (the water } \\
\text { springs). }\end{array}$ \\
\hline $\begin{array}{l}\text { Unchanged Hungarian exonym } \\
\text { Changing from French toponym to } \\
\text { Hungarian exonym }\end{array}$ & Fèn to Fez \\
\hline
\end{tabular}

\begin{tabular}{|c|c|c|c|c|c|c|c|c|}
\hline $\begin{array}{l}\text { City name in French, } \\
\text { Arabic, and IPA }\end{array}$ & $\begin{array}{c}\text { Középisk. } \\
\text { Földr. Atlasz } \\
1909\end{array}$ & $\begin{array}{c}\text { Kogutowicz } \\
\text { Manó Földr. } \\
\text { isk. atlasza } \\
1913\end{array}$ & $\begin{array}{c}\text { Földr. atlasz } \\
1936\end{array}$ & $\begin{array}{c}\text { Ideiglenes } \\
\text { földrajzi } \\
\text { térképfüzet } \\
1946\end{array}$ & $\begin{array}{c}\text { Földr. atlasz } \\
\text { a középisk. } \\
\text { számára } \\
1962\end{array}$ & \begin{tabular}{|c|} 
Földr. atlasz \\
a középisk. \\
számára \\
1973
\end{tabular} & $\begin{array}{c}\text { Földr: atlasz } \\
\text { az ált. isk. } \\
\text { 6-8. oszt. } \\
\text { számára } \\
1988\end{array}$ & \begin{tabular}{|c} 
Földr. atlasz \\
a 12-16 \\
éves tanulók \\
számára \\
2002 \\
\\
Középisk. \\
földr. atlasz \\
2010 \\
\end{tabular} \\
\hline $\begin{array}{l}\text { Alger (DZ) } \\
\text { / الجزائر / العاصمة-zaza?ir/ }\end{array}$ & Alger & Alger & Algir & Alger & $\begin{array}{c}\text { Algír } \\
\text { (Alger) }\end{array}$ & $\begin{array}{l}\text { Algír } \\
\text { (Alger) }\end{array}$ & $\begin{array}{l}\text { Algír } \\
\text { (Alger) }\end{array}$ & Algír \\
\hline $\begin{array}{l}\text { Bizerte / Bizerta (TN) } \\
\text { بنزر/binzart/ }\end{array}$ & & & & Bizerte & Bizerte & Binsert & Binzert & \\
\hline $\begin{array}{l}\text { Fès (MA) } \\
\text { فاس/fa:s/ } \\
\end{array}$ & $\mathrm{Fez}$ & $\mathrm{Fez}$ & Fez & & Fès & $\begin{array}{l}\text { Fes } \\
\text { (Fès) }\end{array}$ & Fez & $\mathrm{Fez}$ \\
\hline $\begin{array}{l}\text { In Salah / Ain Salah (DZ) } \\
\text { / عين صالح/ajn saləh/ }\end{array}$ & & & & In Sallah & In Sallah & Ain Salah & Aïn Salah & In Salah \\
\hline $\begin{array}{l}\text { Kairouan (TN) } \\
\text { /lqajorawan/ }\end{array}$ & & & & Kairuan & Kairouan & Kairuan & & \\
\hline $\begin{array}{l}\text { Laâyoune (MA) } \\
\text { العيو/ / l1-\{ojo:n/ } \\
\end{array}$ & & & & & El-Aiún & & El-Aaiun & El-Aiún \\
\hline $\begin{array}{l}\text { Larache (MA) } \\
\text { / العر ائُ-Yl-Yara?ij/ }\end{array}$ & & $\begin{array}{l}\text { Larache } \\
\text { (El Arais) }\end{array}$ & & Larache & & & & \\
\hline $\begin{array}{l}\text { Le Kef (TN) } \\
\text { ف/Il'ke:f/ }\end{array}$ & & & & & Le Kef & El-Kef & & \\
\hline $\begin{array}{l}\text { Oujda (MA) } \\
\text { وجد/wazda/ }\end{array}$ & & Udjda & & & Oujda & Oujda & & Oujda \\
\hline $\begin{array}{l}\text { Tétouan (MA) } \\
\text { تطو /tit }{ }^{\uparrow} \text { wan/ }\end{array}$ & & Tetuán & Tetuan & Tetuan & Tetuán & Tétouan & & Tétouan \\
\hline $\begin{array}{l}\text { Tunis (TN) } \\
\text { تونس:tu:nIs/ }\end{array}$ & Tunisz & Tunisz & Tunisz & Tunis & Tunisz & Tunisz & Tunisz & Tunisz \\
\hline
\end{tabular}

Table 1. Extract of data records showing the orthographic variants

the international transcription, French transcription accepted as international, or maybe a kind of transliteration according to the Hungarian tradition.

"Maps are more than simply innocent repositories of name data. They work - through their textual authority and repeated use - to normalize certain ways of knowing and naming the landscape over others." (Melville, 2006). The collection of name variants allowed us to distinguish between different variations. These variations can be viewed more generally in terms of orthographic and colonial or historical changes (as seen in Tables 1 and 2), or they can be presented more specifically, highlighting the various types of changes. Due to the limited pages, this discussion will touch on both approaches, with more focus on the 'orthographic vs. historical/ colonial' analysis.

Marrakech showed a rather consistent spelling, except in 1973 Atlas, where it was presented as
'Marrákes' following the Hungarian pronunciation. Some city names were recorded only once in the 1981 and 1987 atlas, where Thyna appeared as Thaenae, Timgad as Thamugadi, Utique as Utica, Cherchel as Caesarea, and Béjaïa as Bougie. Indeed, "placenames act as an intermediary between present and past geographical realities. Place-names usually denote localities of today, which may or may not be the same as the original denotation." (Gammeltoft 2016). Moreover, place 
Malak Alasli: Maghrebian toponym variants in Hungarian school atlases

\begin{tabular}{|c|c|c|c|c|c|}
\hline $\begin{array}{c}\text { City name in French, Ara- } \\
\text { bic, and IPA }\end{array}$ & $\begin{array}{c}\text { Földr. atlasz } \\
1936\end{array}$ & $\begin{array}{c}\text { Ideiglenes } \\
\text { földrajzi } \\
\text { térképfüzet } \\
1946\end{array}$ & $\begin{array}{c}\text { Földr. atlasz } \\
\text { a középisk. } \\
\text { számára } \\
1962\end{array}$ & $\begin{array}{c}\text { Földr. atlasz } \\
\text { a középisk. } \\
\text { számára } \\
1973\end{array}$ & $\begin{array}{c}\text { Földr. atlasza } \\
\text { 12-16 éves tan- } \\
\text { ulók számára } \\
2002\end{array}$ \\
\hline $\begin{array}{l}\text { Annaba (DZ) } \\
\text { عنابة/Snaba/ }\end{array}$ & & Bône & $\begin{array}{c}\text { Bône } \\
\text { (Annába) }\end{array}$ & Annaba & Annaba \\
\hline 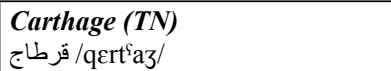 & & & & & Karthágó \\
\hline $\begin{array}{l}\text { Dakhla (MA) } \\
\text { الداخلة/Pdaxla/ }\end{array}$ & Villa Cisneros & & Villa Cisneros & & \\
\hline $\begin{array}{l}\text { El Menia / El Ménéa (DZ) } \\
\text { المنيعة/21-məni:Sa/ }\end{array}$ & & El Golea & & & \\
\hline \begin{tabular}{|l|} 
Ksar El Kébir (MA) \\
القصر الكبير /?1-qas'r lkabi:r/
\end{tabular} & & & Alcázarquivir & $\begin{array}{c}\text { Alcázarquivir } \\
\text { (Ksar El-Kebir) }\end{array}$ & \\
\hline $\begin{array}{l}\text { Sidi Ifni (MA) } \\
\text { إفيدي /sidi Pifni/ }\end{array}$ & Ifni & Ifni & Ifni & & \\
\hline \begin{tabular}{|l|} 
Skikda (DZ) \\
/ski:kda/ \\
\end{tabular} & & Philippeville & Philippeville & Skikda & \\
\hline $\begin{array}{l}\text { Sousse (TN) } \\
\text { سوس:su:sæ/ }\end{array}$ & & & Sousse & Sousse & \\
\hline
\end{tabular}

Table 2. Extract of data records showing colonial or historical variants with ISO2 country codes (DZ = Algeria, MA = Morocco, TN = Tunisia)

names may "render a certain version of history" (Rose-Redwood et al. 2010). Thus, the etymology behind the colonial variants can be explained as follows; 'Alhucemas' and 'Alcázarquivir' was the Spanish naming, 'Ifni' used to be a Spanish province, whereas 'Villa Cisneros' is the Spanish naming in honour of Francisco Cardinal Jimenez de Cisneros. In addition, 'Philippeville', 'Bône', 'Bougie' were the naming during the French occupation, and 'Hadrumetum' was the village of Hammeim, which is now part of Sousse. Besides, 'Cirta' was an ancient Berber and Roman settlement and is a Punic transcription of an existing Berber place name that was later latinized. Moreover, 'Theveste' and 'Caesarea' were a Roman colony, and 'Thamugadi' was a Roman Berber city with the full name of Colonia Marciana Ulpia Traiana Thamugadi. 'Carthago' is a Latin naming, and 'Utica' is because of an unusual latinization of the Punic name 'TQ' or 'TG'.

Furthermore, the various forms of changes can be classified in more detail as follows.

In transliteration, the same character in the original script is always replaced with the same Roman character and is often combined with a dot, line, tilde, or some other diacritic above or below the letter. In transcription, the source language (SL) sounds are rendered as faithfully as possible in the target language (TL). The toponym in non-Latin writing constitutes an additional difficulty because their transliteration in Latin script already introduces more or less divergent phonetic interpretations of the original language. In order to resolve any further phonetic ambiguity, the transliteration focused mainly on the French official name as Arabic contains certain phonemes that do not exist in the Hungarian language.

"The Hungarian written language reflects the pronunciation more accurately than the French or English. The accented vowels (a-á, e-é) may seem peculiar, but they are logical and rational." (Balázs 1997). In the case of the Arabic /w/ (voiced labiovelar approximant) which is absent in Hungarian, the close transliteration is /ou/ similar to the French $/ \mathrm{u} /$. For the Arabic /x/ (voiceless velar fricative), and the French / $\mathrm{R} /$ which is quite close to the Arabic „kh”, Hungarians pronounced it as the voiceless velar plosive / $\mathrm{k} /$; for the toponym Dakhla / daxla/, 'dakla' was used. Moreover, to avoid ambiguity, the transliteration of /fas/ was avoided; the old Hungarian exonym, adopted from an old French version, Fez was adopted. For the Arabic definite article al- (Arabic: /al/), 'el' was found to be easier than 'al'; for the toponym Al Hoceïma, 'el huszima' was used instead of 'al huszima'. The 'á' was used for the /xa/ sound, whereas ' $a$ ' was used for the /a/ sound. Besides, the absence of the Arabic/y/ (voiced velar fricative) in the
Hungarian language was challenging in the transliteration process.

Tanger is shown as 'Tandzsa' in Cartographia, but 'Tanzsa' in a dictionary written by the Hungarian Academy on the transcription of eastern languages such as Arabic and Japanese. What might explain the three pronunciations for the same toponym is that 'Tanger' is the reading of the name, 'Tanzsa' is from the French, while 'Tandzsa' is from Arabic.

It is generally perceived that pronunciation variants are primarily based on personal knowledge and proficiency. However, it is also believed that it is possible to detect 'typical' variants for speakers with a common native language background.

Phonetic adaptation requires some knowledge of the potential pronunciation variants occurring in different speaker groups: intralingual or dialectal variation. Thus, the transliteration was put forward with the help of Hungarian native speakers to ease the pronunciation. Moreover, the Hungarian world atlas of Cartographia provides the transliteration of the names in the names index, e.g., Sousse [Szúsza], which is regulated by the Arabic name Sūsa. However, this attempted transliteration offers another variant [szüsz] which is influenced by the French spelling Sousse; the choice of a $\ddot{u}(/ \mathrm{y} /$ sound, higher pitched than ú) was driven by the fact that it is similar to the ' $u$ ' in the French ' $t u$ '. 
Malak Alasli: Maghrebian toponym variants in Hungarian school atlases

\begin{tabular}{|l|c|c|}
\hline French toponym & Common, bad Hungarian pronunciation & $\begin{array}{c}\text { Hungarian, correct transliteration } \\
\text { according to Ligeti (1981) and } \\
\text { Cartographia (2019) }\end{array}$ \\
\hline Béchar & $\begin{array}{c}\text { /bekar/ } \\
\text { Unfamiliar consonant cluster ch' }\end{array}$ & Bésar \\
\hline Béja & /beja/ & Bédzsa \\
\hline Béjaïa & /bejaja/ & Fedzsája \\
\hline Figuig & /figwig/ & Larás \\
\hline Larache & /laranke/ & Vezzán \\
\hline Ouezzane & /fidifni/ & Udzsda \\
\hline Oujda & //kikda/ & Szkíkda \\
\hline Sidi Ifni & & Szúsza \\
\hline Skikda & The cartography students pronounced it with the /s/ sound; they \\
\hline Sousse & They pronounced it with the Hungarian /g/ (Voiced velar plosive) & Tanger, \\
\hline $\begin{array}{l}\text { Tanger } \\
\text { Arabic: } \text { Tanja }\end{array}$ & /tanger/ & Tanzsa, \\
\hline
\end{tabular}

Table 3. Extract of the attempted transliteration of Maghrebian toponyms

\section{Conclusion}

This paper is a concordance study on place names of the Maghreb region (Morocco, Algeria, and Tunisia). The entries in this concordance represent an amalgam of all known variants for each toponym. The establishment of links between the entries and the names of a large body of reference would make it possible to give, in the form of a concordance, representative of the actual use of the toponym. The syntactic structures and the variation would thus be accessible in context.

This work also allowed to provide information to Hungarians on the official names of foreign places, in the case of occurring changes; for instance, 'El-Goléa, Algeria' (used in a latest edition of a school atlas) has now the official name of 'El Ménia'. It will also serve as a reference for knowing the correct and precise forms of place names' pronunciation.

Two main conclusions emerged from the interviews; Hungarian students encountered challenges reading the toponyms, and Arabic speakers could not identify the names either, which causes a cut in communication. Hungarians are more or less familiar with the English and German words and pronunciation. However, with French words, they do not only look but also sound strange to Hungarian as only one or two percent of the people can read something written in French or according to French pronunciation, which could be one of the reasons why the recorded Hungarian pronunciation of Maghrebian place names was not entirely understandable by others.

There are many ways that geographical names can vary. Given the many sources of variation, it is not unreasonable for a single geographical place to have several ways of being represented textually. This causes problems for full text searching because searchers tend to enter only one form as the search term, meaning that resources using only variant forms are not retrieved in the search. Information retrieval systems that use cross references or systems such as the Semantic Web that automatically search or link geographic place name variants are essential in enabling quality geographical research.

In order for geographical names to fulfil their functions, the relationship between geographical names, the places they designate and the message they convey must be clear, obvious and well understood at the level of individuals, the community, in the region, as well as at national and international levels. The toponyms thus become a communication code which guarantees the univocity of the place names and their fixation. Toponym should preserve place names identification both in writing and oral form.

\section{Recommendations}

Since what the geography teacher says is usually what the students believe to be authentic, the recommendations should be relevant not only for the publishers but also for the teachers and geographic teacher training.

It would be ideal if the teachers could at least understand the fundamentals of how to pronounce foreign Arabic names, and an explanation of why they are spelled that way. Easy-topronounce names are easier to recall and promote topographical awareness. They are often more commonly used, which promotes topographical accuracy in communication. As an introduction to the gazetteer of these school atlases, there should be some linguistic context. For geography students, an introductory text with a standard pronunciation of Maghrebian geographical names would be an interesting addition. It may have a pronunciation key with spelling and pronunciation examples. The IPA alphabet will add depth, but it will necessitate some linguistic knowledge. It would also be helpful to explain to the teachers why, for example, they may find Casablanca at times, and Dar elbeïda or Ad-Dār al-Bayḍā at other times.

Moreover, it could be valuable to students to have an introduction to the index, which provides some information on the main names and their descriptions. This may also be a solution if the different publishers use the same system of writing the names, the case of French names, which could have the Hungarian pronunciation of at least the major names in parenthesis, either because they are major cities 
or are important. However, we should bear in mind that adding a second name consumes a significant amount of map surface and can cover a road, a river, a country border, or some other essential details. Furthermore, each name must specifically refer to the related object to prevent ambiguity. Consequently, a name must not be isolated from the object to which it refers, nor should it be written in such a way that it is unclear to which object it denotes. As a result, it should not and cannot be a complete addition of Hungarian pronunciation.

It is also worth noting that, according to a unique Hungarian practice, certain places under British rule were written in Hungarian. However, for areas under French control, they consistently followed the French way rather than the Hungarian. This takes a different approach to presenting place names in the Arab world, and it would be advantageous if the teachers could elaborate on this point. The difference in the presentation of Arab place names can be attributed to the fact that they were either under British or French control.

Most guidelines advise placing the exonym first on maps and in written documents, stating that it is the name that should be considered first, while also advising rendering the endonym in brackets - at least at the largest map scale and when a name appears for the first time in a written document. Exonyms are widely used in publications with an educational purpose (school atlases). Pronunciation is not a vital concern in map interpretation; however, atlases must adhere to textbooks, which may motivate the use of exonyms. Moreover, pronunciation is crucial in oral practice. Thus, the concern of correctly pronouncing the endonym or choosing the safe way of using the exonym.

For this part of North Africa, Hungary lacks a real exonym or at least one very distinct from the endonym. Algeria, Morocco and Tunisia display a bilingual toponymic landscape with an Arabic endonym and a French exonym. They are usually written in a conventional manner that follows the principles of French orthography.
Using the French exonyms, which have an official status and are commonly used throughout the country, is a good approach. However, since French is not a widely spoken foreign language in Hungary, pronunciation can be challenging.

Tourist maps and travel books help non-locals get around. They are explicitly designed to meet the needs of travellers in terms of preparing for their journey. As a result, the content is tailored to the target audience's expectations. Hence, it is common for the writing of geographical names to adhere to the convention of prospective travellers, which does not always adhere to the locally used convention. Since they are useroriented, they are written in the target group's native language, or at the very least in a language that the group is familiar with. In some cases, some geographical names in leaflets or travel publications do not correspond with the name form at the destination, and problems may occur if the tourist only finds the local endonym rather than the exonym. Editors of travel publications and tourist maps have the responsibility to include all name types of a geographic name. The user must find the endonym(s) and exonym. If the endonym is written in a different language, the original spelling and a romanized version should be given.

\section{References}

Akioud, H. (2018). Toponymie marocaine et la langue amazighe: Enjeu et défis de normalisation. 4, pp. 21-47.

Balázs, G. (1997). The Story of Hungarian: A Guide to the Language. Corvina Books, Budapest.

Boujrouf, S. - Hassani, E. (2008). Toponymie et recomposition territoriale au Maroc: Figures, sens et logiquesToponymy and Territorial Restructuring in Morocco: Figures, Meaning and Logics. L'Espace Politique, 5(5), pp. 40-52.

DOI: $10.4000 /$ espacepolitique. 228

Cartographia (2019). Földrajzi világatlasz. Budapest.

Caubet, D. (2008). Morocco (Vol. 3, pp. 287-297).

El Fasi, M. (2005). La toponymie et l'ethnonymie, sciences auxiliaires de l'histoire. In : Ethnonymes et toponymes africains, pp. 19-24.

Földrajzi atlasz (1936). Szent István Társulat, Budapest.

Földrajzi atlasz a 12-16 éves tanulók számára (2002). Cartographia Kft., Budapest.
Földrajzi atlasz a középiskolák számára (1962) Kartográfiai Vállalat, Budapest.

Földrajzi atlasz a középiskolák számára (1973). Kartográfiai Vállalat, Budapest.

Földrajzi atlasz az általános iskola 6-8. osztálya számára (1988). Kartográfiai Vállalat, Budapest.

Gammeltoft, P. (2016). Names and Geography. In: The Oxford Handbook of Names and Naming Edited by Carole Hough Print, pp. 1-15. DOI: 10.1093 oxfordhb/9780199656431.013.58

https://nyak.oh.gov.hu/doc/stat/stat disp. asp? strID $=\mathrm{A} 0$

https://unstats.un.org/unsd/ungegn/

Ideiglenes földrajzi térképfüzet a közép- és középfokú iskolák részére (1946). Magyar Földrajzi Intézet R.T., Budapest.

Jordan, P. (2016). Place names as an expression of human relations to space. ICOS 2014. Names and their environment. Proceedings of the 25th International Congress of Onomastic Sciences, 25-29 August 2014, Glasgow.

Kogutowicz Manó Földrajzi iskolai atlasza (1913, XI. bôvített kiadás). Magyar Földrajzi Intézet R.T., Budapest.

Középiskolai Földrajzi Atlasz (1909). Magyar Földrajzi Intézet Rt., Budapest.

Középiskolai földrajzi atlasz (2010). Cartographia Tk, Kft., Budapest.

Ligeti, L. (1981). Keleti nevek magyar helyesírása. Akadémiai Kiadó, Budapest.

Melville, A. (2006): Mapping the wilderness toponymic constructions of Cradle Mountain/Lake St. Clair National Park, Tasmania, Australia. Cartographica 41, pp. 229-245.

Nissabouri, A. (2006). Toponymes maghrébins. De l'enracinement à l'internationalisation. Cahiers de Sociolinguistique, pp. 117-143.

Orth, D. J. - Payne, R. L. (2003). Principles, policies, and procedures: Domestic Geographic Names. U.S. Board on Geographic Names. http://geonames.usgs.gov/pppdgn.html

Rose-Redwood, R. - Alderman, D. - Azaryahu, M. (2010). Geographies of toponymic inscription: New directions in critical place-name studies. Progress in Human Geography, 34(4), pp. 453-470. DOI: $10.1177 / 0309132509351042$

Yamaguchi, K. (1974). Chizu to chimei [maps and place names]. Kokon Shoin, Tokyo.

Zagórski, B. R. (2010). Endonyms versus exonyms : A case study in standardization. With a list of names of Arab countries and their major cities.

Zagórski, B. R. (2018). Arabic geographical names in international use: Remarks on the standardization and Romanization UNGEGN Information Bulletin No. 54, pp. 26-30.

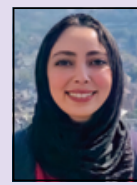

Malak Alasli

PhD student

Institute of Cartography and Geoinformatics, Eötvös Loránd University alaslima.ma@gmail.com 